Cornell Law Library

Scholarship@Cornell Law: A Digital Repository

Cornell Law Faculty Publications

$12-19-2006$

\title{
Harmonizing Preferential Rules of Origin in the WTO System
}

John J. Barceló III

Cornell Law School, jjb16@cornell.edu

Follow this and additional works at: http://scholarship.law.cornell.edu/lsrp_papers

Part of the Antitrust and Trade Regulation Commons

\section{Recommended Citation}

Barceló III, John J., "Harmonizing Preferential Rules of Origin in the WTO System" (2006). Cornell Law Faculty Publications. Paper 72. http://scholarship.law.cornell.edu/lsrp_papers/72

This Article is brought to you for free and open access by Scholarship@Cornell Law: A Digital Repository. It has been accepted for inclusion in Cornell Law Faculty Publications by an authorized administrator of Scholarship@Cornell Law: A Digital Repository. For more information, please contact jmp8@cornell.edu. 


\title{
CORNELL LAW SCHOOL
}

\section{Legal StUdies ReSEARCH PAPER SeRIES}

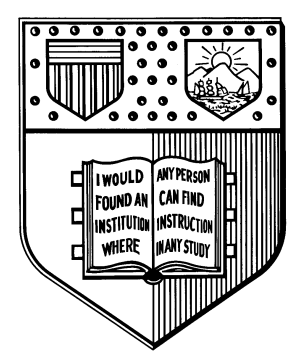

\section{Harmonizing Preferential Rules of Origin in the WTO System}

\author{
John J. Barceló III
}

\author{
Cornell Law School \\ Myron Taylor Hall \\ Ithaca, NY 14853-4901
}

Cornell Law School research paper No. 06-049

This paper can be downloaded without charge from:

The Social Science Research Network Electronic Paper Collection:

http://ssrn.com/abstract=952535 


\section{HARMONIZING PREFERENTIAL RULES OF ORIGIN IN THE WTO SYSTEM}

John J. Barceló III

William Nelson Cromwell Professor of Law

Reich Director, Berger International Legal Studies Program Cornell University School of Law

Ithaca, New York, U.S.A. 14853

Phone: + (607) 255-3604

jjb16@cornell.edu

October, 2006 
Preliminary Draft

October, 2006

\title{
HARMONIZING PREFERENTIAL RULES OF ORIGIN IN THE LIGHT OF WTO DISCIPLINES
}

\author{
John J. Barceló III \\ W.N. Cromwell Professor of Law \\ Cornell University School of Law
}

\section{INTRODUCTION}

Preferential arrangements (bilateral and multilateral free trade areas and GSP systems (preferences for developing countries)) are emerging everywhere in the world trading system and are causing concern because they discriminate against non-members and add complexity, distortions and inconsistency to the global system. Rules of origin (ROOs) linked to these arrangments are a significant part of the problem. More and more they have become the source in their own right of distortions in trade patterns, complexity, non-transparency and inconsistency. This essay argues that WTO members should authorize negotiations seeking to harmonize preferential ROOs (rules of origin linked to preferential arrangements) around core principles consistent with WTO rules. The harmonized preferential ROOs should be aligned as much as possible with the harmonized regime for non-preferential ROOs (rules of origin linked to nonpreferential arrangements) likely to emerge from the current hold-over WTO negotiations authorized by the Uruguay Round ROOs Agreement. They should be nonrestrictive, based essentially on the principle that substantial transformation confers origin, and--except where developing countries benefit-should not allow cumulation (treating product components from within the preferential region as locally produced). This introduction first discusses some fundamentals about ROOs and then explains the structure of the essay. 
Importing countries use ROOs to determine the national origin of imports. Normally substantial processing must occur in the shipment country before a good would be considered to originate there. Sometimes even more than "substantial processing" is mandated. ROOs are the provisions that determine for each product what exactly is required.

ROOs are divided into two fundamental types: preferential and nonpreferential, depending on the nature of the policy instrument to which they are linked. ${ }^{1}$ Preferential ROOs (PROOs) are linked to trade policy instruments, such Free Trade Area (FTA) agreements or Generalized System of Preference (GSP) systems, that accord preferential market access (reduced or zero tariff rates) to imports from select countries (FTA members or developing country beneficiaries of a GSP system). Preferential ROOs determine whether a good has the national origin of a preference country, in which case it gets preferential market access.

Non-preferential ROOs (NPROOs) are linked to policy instruments of a more general nature that do not involve preferential access for goods-for example, a customs regime requiring all imports to bear a mark of origin. These policy instruments involve both neutral and also more politically sensitive purposes, though none involves offering preferential market access. Falling at the neutral--or non-political--end of the spectrum, for example, are programs for collecting trade statistics (bilateral trade balances) and, as stated, for imposing marks of origin on imports. At the politically sensitive end, there are policy instruments for restricting trade from select countries. This category includes such provisions as basic tariff laws (applicability of MFN or non-MFN tariffs),

\footnotetext{
1 Strictly speaking, it is the underlying policy instrument, and not the rules of origin themselves, that accords a preference or that is non-preferential in nature. For convenience, however, the rules of origin associated with these preferential or non-preferential policy instruments have come to be called preferential or non-preferential ROOs, respectively.
} 
selective quotas, selective safeguard measures, antidumping duties, countervailing duties, and government procurement restrictions. Except for statistical and consumer information programs, NPROOs generally decide whether a good will face restricted entry (as opposed to preferential entry) because it comes from a country against which restrictions apply.

In today's world most traded goods contain components from, or are subject to processes in, more than one country. Some goods, however, plainly originate wholly in one country. Examples include animals raised in a single country, non-processed agricultural goods grown and harvested in a single country, and minerals extracted in a single country. For such products ROOs are uniform and non-controversial; they accord origin to that single country. In discussing ROOs this essay excludes such straightforward ROOs applicable to single-country goods and will always refer only to those ROOs applying to goods produced with the use of multiple inputs from, or processes in, two or more countries.

Support for harmonizing ROOs stems from the desire for transparency, simplicity, and reduction of transactions costs in global trade. This essay focuses primarily on harmonizing PROOs. Nevertheless, some understanding of efforts to harmonize NPROOs is essential for a discussion of PROOs, in part because the world trading system is much further along in efforts to harmonize NPROOs and has not yet even seriously considered an undertaking to harmonize PROOs.

This essay contains four major parts. The first part, immediately below, discusses the current state of efforts to harmonize NPROOs. The second part turns to PROOs and discusses the trade distorting effects of preferential regimes, with a particular emphasis on trade distortions attributable to the PROOs 
themselves and not just to the underlying policy instruments to which they are linked. This discussion is important for understanding the issues that arise when one asks (as Part three does) whether certain provisions of exisiting PROOs should be avoided in harmonized rules because those provisions transgress basic WTO principles and rules. Part three, then, turns to a discussion of the relevant WTO rules that may apply to constrain or discipline PROOs. Part four discusses the current EU effort to harmonize ROOs in preferential arrangements to which the EU is a party. This is the best-known example of a serious effort to harmonize PROOs - albeit at only the regional level. The conclusion urges a harmonization effort for PROOs at the WTO level and restates the core principles around which such an effort should be structured. The goal should be clear, relatively easy to apply rules, of a non-restrictive nature, based as much as possible on the emerging harmonized NPROOs and on the fundamental notion that substantial transformation confers origin. The cumulation rule should also be eliminated, unless it benefits a developing country.

\section{NON-PREFERENTIAL ROOS}

Prior to the Uruguay Round, the only significant multilateral effort to harmonize ROOs was promoted by the Customs Cooperation Council (CCC) in Brussels $^{2}$ and led to the inclusion of certain provisions in the 1974 Kyoto Convention. ${ }^{3}$ Those provisions did not distinguish between preferential and non-preferential ROOs and were not binding in any event. They merely set down preferred guidelines for ROOs. For goods processed in more than one country the Kyoto Convention endorses the "last significant transformation" concept as the main origin determining principle. For further precision the

\footnotetext{
${ }^{2}$ Bernard Hoekman, "Rules of Origin for Goods and Services," 27 Journal World Trade Law 81, 84 (Issue 4, 1993).

3 International Convention on the Simplification and Harmonization of Customs Procedures, Annex D.1.A, 18 May 1973, S. Treaty Doc. No. 23, $97^{\text {th }}$ Cong., 2d Sess. (1982).
} 
convention lists other alternatives that a country could employ to help determine whether the "significant transformation" threshold had been crossed: i) change in tariff heading (origin is conferred where various components are processed to produce a final product that falls under a different Harmonized System tariff heading from the heading applicable to each of the components); ii) specific processing operations; and iii) value added requirements. ${ }^{4}$ These are the primary origin-determining mechanisms most countries currently use.

\section{Uruguay Round ROOs Agreement and Harmonization}

Because the GATT contains almost nothing on ROOs, ${ }^{5}$ the Uruguay Round ROOs Agreement, which entered into force along with the other WTO agreements on January 1, 1995, is the main WTO instrument dealing directly with ROOs. The agreement's purpose is to achieve a harmonized set of ROOs, but it deals essentially only with NPROOs. A Common Understanding applicable to PROOs was added as Annex II of the agreement, but it is of limited significance. It deals essentially with transparency goals, not harmonization, and includes such requirements as notifying the WTO of all PROOs, providing clear definitions, responding promptly to trader inquiries, and ensuring due process is followed in determinations and review procedures. The agreement's separate and minimalist treatment of PROOs presumably reflects the greater political sensitivity that surrounds these provisions.

The main goals of the ROOs Agreement are: first, to create a multilaterally agreed set of harmonized NPROOs for all products in the Harmonized System nomenclature, which ROOs would then be used for all

\footnotetext{
${ }^{4}$ Hoekman '93 supra at 84.

${ }^{5}$ GATT Article IX provides for MFN treatment on marks of origin, which would apply anyway, and not much else concerning ROOs.
} 
NPROOs purposes; ${ }^{6}$ second, to set forth the main principles that will govern application of the harmonized NPROOs once they are adopted and enter into force; ${ }^{7}$ and third, to establish the main principles that will govern application of NPROOs during the transition period, which applies until the harmonization work is completed (presumably meaning until the harmonized rules enter into force) ${ }^{8}$

Although the deadlines set out in the ROOs Agreement for the harmonization project have not been met, the harmonization work program has made substantial progress and seems near completion, though the results have not yet been made public. ${ }^{9}$ Article 9(1) sets out the fundamental principle that has guided this work. A good is to have the origin of the country in which the "last substantial transformation" occurs—-the core principle of the 1974 Kyoto Convention. This has the practical significance that customs officials in the importing country generally need only consider the production processes occurring in the country of immediate export, if the transformation there is sufficient.

Article 9(2) deals with how to make the "last substantial transformation" test operational. First, the Technical Committee is to define certain minimal processes that by themselves would not be sufficient to bring about substantial

\footnotetext{
${ }^{6}$ ROOs Agreement Art. 9

${ }^{7}$ ROOs Agreement Art. 3

${ }^{8}$ ROOs Agreement Art. 2.

9 Some observers are pessimistic about the prospects for a successful outcome of the ongoing negotiations. See Asian Development Bank, Asian Development Outlook 2006 at 279 (on line at http://www.adb.org/Documents/books/ado/2006/documents/ado2006-part3.pdf.) (“At a multilateral level, the 'harmonization' program in nonpreferential rules of origin at WTO has dragged on for more than 10 years and is still not close to being realized.”) A major obstacle to final agreement is the issue of scope of coverage of the harmonized ROOs. Although the ROOs Agreement itself provides in Article 1(2) for very broad coverage, disagreement seems to exist over whether anti-circumvention measures applicable to anti-dumping and countervailing-duty orders in some countries, namely the United States and the EU, should be included in the coverage of the harmonized ROOs. Exclusion of the anti-circumvention regimes might be the best option, especially if this would produce a less restrictive set of harmonized NPROOs.
} 
transformation. Second, and more important, the Technical Committee is to define for each product in the HS nomenclature, what constitutes "substantial transformation”. How is this to be done? Article 9(2) explains.

\section{Change in Tariff Heading (CTH)}

Article 9(2) uses, as its fundamental approach, change in tariff classification where intermediate products are combined or processed to make a final product. Supplemental tests for exceptional cases augment this basic approach where processing that would meet the change-in-tariff-classification test would nevertheless not involve a substantial transformation. The goal for the generally applicable change-in-tariff-classification approach is to choose the smallest tariff classification change that is consistent in most cases with the "substantial transformation” principle. ${ }^{10}$ Opting for the smallest tariff classification change as the generally applicable rule means that the test is sometimes overinclusive (including production processes that achieve the required tariff classification change without truly involving a "substantial transformation”). The supplemental tests are employed to deal with these exceptional cases.

The HS nomenclature is divided into 21 sections (the most general category); 96 chapters (captured by the first two digits of the harmonized tariff code); a large number of "headings" under each chapter (captured by the next two digits—sometimes referred to as the four digit level); a still larger number

\footnotetext{
10 ROOs agreement Article 9(2)(c)(ii) provides: “The Technical Committee shall consider ***, on the basis of the criterion of substantial transformation, the use of change of tariff subheading or heading when developing rules of origin for particular products or a product sector and, if appropriate, the minimum change within the nomenclature that meets this criterion." (emphasis added) The "if appropriate" qualifier is not explained. Perhaps it means that a minimum change need not be used if a substantial transformation would not occur in a large number of cases in which the change of tariff classification requirement had been met. That a change at the subheading level (the six digit level) is listed before a change at the heading level (the four digit level) seems further to state a preference for the smallest tariff classification change that would satisfy "substantial transformation.”
} 
of "sub-headings" under each "heading” (captured by the next two digitssometimes called the six digit level); and still more detailed levels of differentiation beyond—sometimes called the "statistical level". Allowing a tariff classification change at the eight digit level to suffice would generally mean an easily-satisfied or liberal test; whereas requiring a change at the chapter—or two digit level—would generally be more restrictive, requiring more processing.

One of the major advantages of the change-in-tariff-heading (CTH) method is its relative ease of administration for customs officials and its inexpensiveness and predictability for private firms ${ }^{11}$--at least as compared to the alternative methods (specific processing--which must deal with constant technological innovation--and value adde--which must confront auditing expense, uncertainty, delays, and price and exchange rate changes). The dark side of the change-in-tariff-heading method is its technical complexity and the opportunity this affords special interests to capture the definitional process. David Palmeter has pointed out that generalists cannot truly understand the rationale behind particular requirements of shifts in tariff headings, subheadings and statistical headings. ${ }^{12}$ Only specialists in the relevant business sector, who work day in and out with the subcomponents, components, and end products and the processes involved in putting them together, will truly understand the meaning and significance of the terms and descriptions in the headings and subheadings. The specialist, then, can take advantage of the complexity and nontransparency to advance special interest causes without it being clear to nonspecialists who gains and who loses.

\footnotetext{
11 David Palmeter points out that the CTH method, though perhaps on balance the least costly and clearest, is nevertheless not without costs (e.g., maintaining records of input origins and classifications), classification conundrums, and other disadvantages. See David Palmeter, The WTO as a Legal System-Essays on International Trade Law and Policy 141; 150-152 (2003)

12 David Palmeter, The WTO as a Legal System-Essays on International Trade Law and Policy 151 and 159 (2003)
} 
Several features of this harmonization effort forecast that a relatively "neutral" and non-restrictive set of harmonized ROOs is likely to emerge. As noted, the "last substantial transformation" concept is the guiding principle, and the "minimum change within the nomenclature that meets this criterion"13 is to be chosen. Thus a country will not be authorized to use, for example, the "most significant transformation” test, which can more easily be manipulated to assign a product an origin that will trigger a quota or selective safeguard restriction. The agreement also provides forthrightly that ROOs: “*** should not be used as instruments to pursue trade objectives directly or indirectly. They should not themselves create restrictive, distorting or disruptive effects on international trade." $^{14}$

Once the harmonized NPROOs are agreed upon, they are to be added as an annex to the ROOs Agreement. A Ministerial Conference is then to decide the time-frame for their entry into force. ${ }^{15}$ If this is achieved, it will add greater rationality, transparency, and efficiency to trade transactions. It will also provide an important multilateral standard representing an agreed-upon set of neutral, non-restrictive ROOs identifying essentially when a product can legitimately be said to have experienced a substantial transformation for origin purposes. Such a standard could play an important role in subsequent efforts to harmonize PROOs and--in the absence of such harmonization--in employing WTO rules to discipline their use. We turn now to this essay's main topic: preferential ROOs.

\footnotetext{
${ }^{13}$ ROO Agreement Article 9(2)(c)(ii).

${ }^{14}$ ROO Agreement Article 9(1)(d).

${ }^{15}$ ROO Agreement Article 9(4).
} 


\section{PREFERENTIAL ROOS}

The two main forms of preferential arrangements for which ROOs apply are first, those resulting from regional and bilateral free trade agreements (FTAs) and second, those involving unilateral (non-reciprocal) preferential access granted by industrial countries to certain goods coming from developing countries under a Generalized System of Preference (GSP) regime. Both arrangements violate the core non-discrimination principle of the WTO. FTAs are nevertheless authorized under the conditions set out in GATT Article XXIV. GSP systems are authorized by the "Enabling Clause" adopted in a 1979 GATT Decision. ${ }^{16}$

Preferential arrangements are widespread in the world trading system. By one estimate approximately 300 bilateral and multilateral free trade agreements and customs unions will be in effect by 2007. ${ }^{17}$ Almost all countries belong to one or more preferential arrangements. A large percentage of total world trade is now subject to at least one of these arrangements or to a GSP system. For example, the EU now applies its MFN tariff to only nine trading partners. ${ }^{18} \mathrm{~A}$ quick glance at World Bank charts showing the multiple overlapping memberships and hub and spoke features of these arrangements explains the origin of the "spaghetti bowl" epithet for these systems. ${ }^{19}$ The lines sketching the membership links in these agreements resemble the criss-crossing

\footnotetext{
${ }^{16}$ See GATT, $26^{\text {th }}$ Supp. Basic Instruments \& Selected Documents (BISD) 203 (1980).

17 Peter Sutherland, Jagdish Bhagwati, Kwesi Botchwey, Niall Fitzgerald, Koichi Hamada, John H. Jackson, Celso Lafer, \& Thierry de Montbrial, The Future of the WTO at 22 (WTO, Switzerland, 2004). See also, The World Bank, Global Economic Prospects-Trade, Regionalism, and Development 2005 (The World Bank: Washington, D.C. 2005) (Chapter 2: Regional Trade and Preferential Trading Arrangements: A Global Perspective). According to the Asian Development Bank some estimates predict 300 bilateral agreements alone by the end of 2006. Asian Development Bank, Asian Development Outlook 2006 at 276 (on line at http://www.adb.org/Documents/books/ado/2006/documents/ado2006-part3.pdf.)

${ }^{18}$ These include: Australia; Canada; Chinese Taipei; Hong Kong; China; Japan; Korea; New Zealand; Singapore; and the US. The Future of the WTO, supra at 21 and fn 11.

19 The World Bank 2005 supra at 39.
} 
entanglements of spaghetti strings in a bowl. The large number of these systems and the variety, inconsistency, and complexity of their ROOs add substantial compliance costs for traders serving multiple markets and for customs officials in those markets.

For those who see value in these arrangements, excessive compliance costs are undesirable, and harmonization of ROOs could be an attractive remedy. When multiple ROOs vary or conflict, producers and traders cannot be sure that a single production run, with a certain make-up of components and value added, will satisfy all relevant ROOs. If more than one production run is needed to satisfy different sets of ROOs, returns to scale are lost.

Of course if one opposes these discriminatory regimes in the first place, increased compliance costs might be welcomed as a desirable deterrent to their use. If the compliance costs are too high, traders will simply forego preferences and pay the MFN tariff. This is not an infrequent occurrence. Nevertheless, even for those who would prefer to dismantle discrimination in the world trading system, a harmonization project for PROOs could be seen as worthwhile. Preferential arrangements exist, and traders must take them into account in their business plans. Hence simplification and harmonization of ROOs would still be a rational end in itself- the purpose being to improve transparency in the trading system and reduce unavoidable and wasteful compliance costs that to some extent must be incurred even for a trader to know whether it would pay to take advantage of a preference.

In the discussion below, this essay will focus primarily on the desirable content of a harmonized set of PROOs. There is currently no WTO mandate for such a harmonization program. In 1996 Japan proposed that the Committee on Rules of Origin undertake such a project for regional integration schemes 
because of their growing number and the distorting effects on countries outside the region. ${ }^{20}$ Although most of the members spoke against this proposal, four countries supported it (Australia, Hong Kong, Korea, and Pakistan). ${ }^{21}$ Once NPROOs have been harmonized, interest in turning to PROOs may increase. In any event harmonization would improve the workings of the world trading system and certainly should be pursued as one of the ways of curtailing potential distortions from the ever larger number of preferential arrangements on the global scene.

To understand the underlying policy issues at stake, I turn first to a brief discussion of the main trade distorting features of preferential arrangements, but primarily of the ROOs linked to them. The ROOs themselves play an independent role in exacerbating the level of trade distortion involved. An understanding of the relevant distortions at stake is important, not only for understanding how harmonized ROOs of a particular content might help to correct or lessen the relevant distortions, but also for understanding how WTO provisions, namely in Article XXIV and to some extent in the Enabling Clause, might offer grounds for disciplining abusive ROOs and perhaps encourage harmonization centered around curtailing distortions.

\section{Trade Diversion and Preferential ROOs}

The wisdom of allowing FTA and GSP derogations from the core nondiscrimination principle (MFN) of the GATT/WTO system is controversial. The main arguments supporting and challenging these arrangements have been

\footnotetext{
20 See Committee on Rules of Origin, Minutes on Meeting on 13 September 1996 at para. 8.4 , World Trade G/RO/M/7 (4 October, 1996).

21 See Committee on Rules of Origin, Minutes on Meeting of 13 September 1996 at paras. 2.9-2.11, World Trade G/RO/M/7/Corr. 11 (10 October 1996).
} 
set out very effectively in The Future of the WTO report ${ }^{22}$ and in the paper by Barry Desker and Margaret Liang. ${ }^{23}$ I will not repeat these arguments here in any detail. I will concentrate instead on trade diversion in intermediate products, because this is the main way in which ROOs can exaggerate the trade distorting effects of preferential arrangements.

As is frequently discussed in trade writings, preferential access for a final good in an FTA or a GSP system will trigger both trade creation and trade diversion. Trade creation occurs--and is efficiency enhancing--where a leastcost-producer, found within the preferential area, gains increased market access through the elimination of tariffs. Trade diversion occurs — and is distortivewhere the least-cost producer is found outside the preferential area and is displaced within the preference area by a less efficient preference-receiving producer who is freed of the tariffs that the non-member, least-cost producer must face.

Trade diversion is undesirable (because it is inefficient), but those who approve of preferences deem trade diversion an acceptable cost because of the overall benefits deriving from the regime. In the case of FTAs, claimed benefits come from trade creation and other aspects of market integration and political cooperation. In the case of GSP systems, they come from trade creation and, more importantly, from the claimed assistance they offer developing countries in meeting their development goals.

We have been discussing the positive and negative effects of preferential arrangements without distinguishing between final and intermediate products.

\footnotetext{
22 Peter Sutherland, Jagdish Bhagwati, Kwesi Botchwey, Niall Fitzgerald, Koichi Hamada, John H. Jackson, Celso Lafer, \& Thierry de Montbrial, The Future of the WTO Chapter II (WTO, Switzerland, 2004).

${ }^{23}$ Barry Desker \& Margaret Liang, "Prospects for Disciplining Customs Unions, Free Trade Areas and Preferential Trade Agreements” (conference paper).
} 
For our purpose--that of analyzing the potentially distortive role of PROOs themselves-the distinction is important. Distortions associated with PROOs relate primarily to trade diversion in intermediate products, not final products, which the discussion further below will explain.

Paradoxically, ROOs at the extremes of restrictiveness and liberality would do away almost entirely with trade diversion concerning both final and intermediate products, but in an anomalous way. ${ }^{24}$ At the extreme of restrictiveness (e.g., 100\% value added for processed goods), very few processed goods would qualify, ${ }^{25}$ because in the modern production process most products utilize at least some components imported from foreign countries or processes occurring abroad. Hence, with impossibly restrictive ROOs a preference regime would be largely ineffective. No (or very little) trade distortion would occur in processed products, because almost no processed product would qualify for preferential access - and hence all reputed benefits (trade creation and the other development or integrative ends) would also be sacrificed.

At the most liberal end-the complete absence of ROOs--transshipment through a preference country would be allowed and there would again be little or no trade diversion. A least-cost producer in a non-preferred country could gain preferential access merely by transshipping through a preference country. Economists refer to such transshipment as "trade deflection." But here again the purposes of the preference regime would be defeated. Benefits intended for preference countries would be reaped instead by non-preference countries via trade deflection. If just one preference country did not produce the good in

\footnotetext{
${ }^{24}$ I am indebted to Aaditya Mattoo at the World Bank for this observation.

${ }^{25}$ Non-processed goods that are sourced in a single country, such as minerals, animals raised on a farm or unprocessed agricultural goods, would of course qualify. For such goods, however, ROOs are irrelevant, because their origin will be clear under any conceivable set of ROOs. One exception would be fish, where origin could be attributed either to the nationality of the waters where they are caught or to that of the fishing vessels that do the catching.
} 
question, presumably there would be no tariff barriers in that country to prevent or constrain trade deflection. In any event trade deflection could always occur through the country with the lowest tariff barrier. The following diagram illustrates the degree of trade diversion as a function of the restrictiveness of the applicable ROOs.

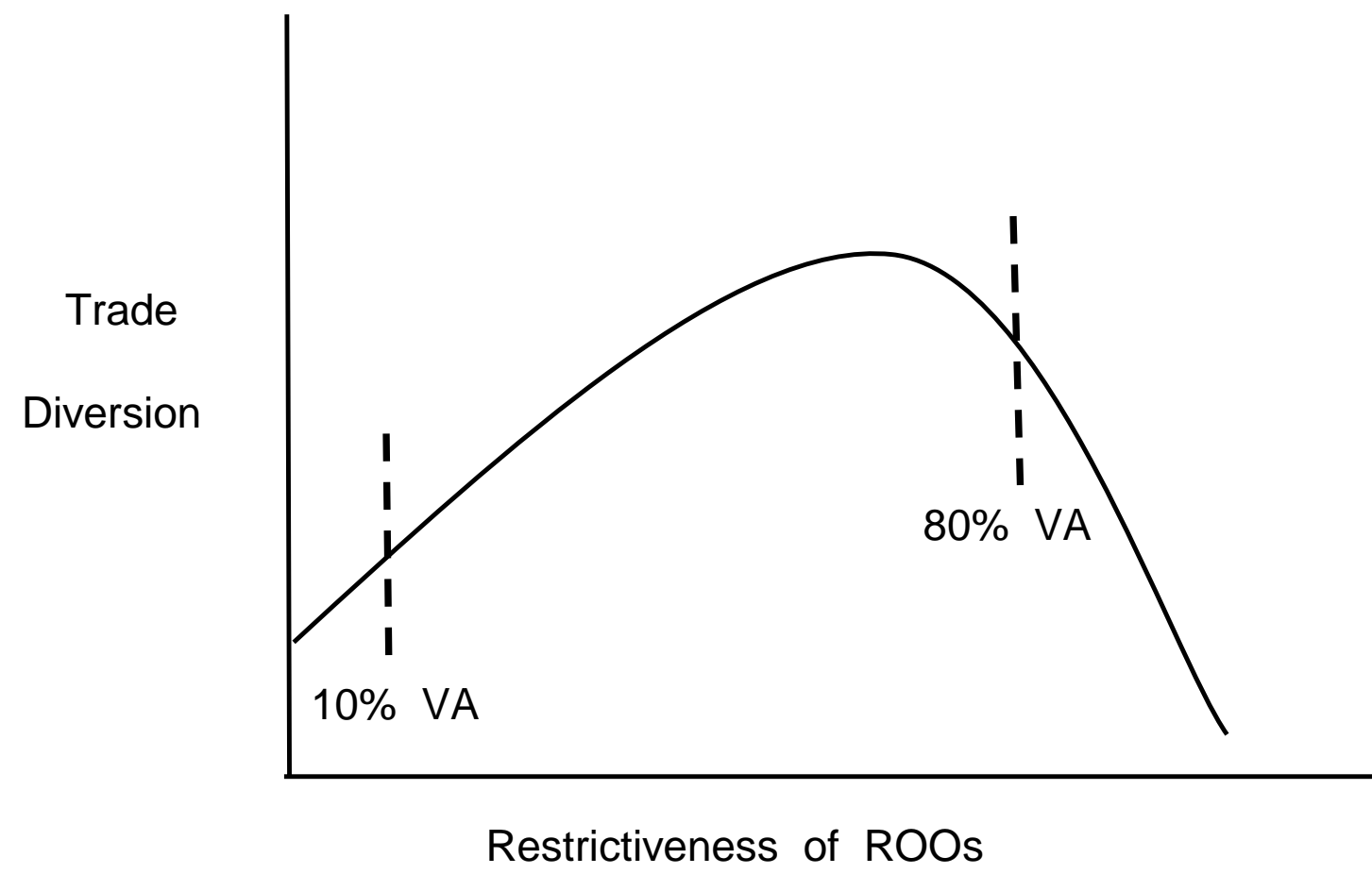

ROOs somewhere between the extremes of maximum restrictiveness and maximum liberality are therefore needed to achieve the purposes of preferential regimes. In that middle range some amount of trade diversion in final products is inevitable - the existence of the preference assures that this will be so. In the case of an FTA, the Article XXIV(8)(b) rule requiring that free trade be achieved with respect to "substantially all trade" seems likely to prevent bilateral or regional agreements aimed primarily at trade diversion. ${ }^{26}$ If it were

${ }^{26}$ For a general discussion of this point, see James Mathis, Regional Trade Agreements in the GATT/WTO: Article XXIV and the Internatl Trade Requirement 113-115 (The Hague, 2002). Mathis cites other scholars who agree that the "substantially all trade" requirement tends to prevent FTAs aimed essentially at trade diversion, including Robert Hudec, Comment on 
not for that requirement one might expect to see many FTAs spring up limited to a few carefully selected final products — where the beneficiaries of trade diversion on both sides of a border would prosper at the expense of more efficient third-country competitors. Thus, if the "substantially all trade" discipline is effectively enforced, it will operate to reduce the element of trade diversion in final products, though some trade diversion will still occur.

In the case of GSP systems, the essential discipline derives from the requirement that these regimes be designed to assist developing countries. This will not reduce trade diversion, but at least the inevitable trade diversion will benefit export-oriented producers in the developing countries. (Of course, those who dispute the wisdom of trade preferences for developing countries would challenge the desirability of this outcome for the long-term development goals of developing countries. ${ }^{27}$ )

Returning to the role of ROOs in preferential regimes, we can see that another form of trade diversion is closely linked to the restrictiveness level of ROOs within the general middle range that will apply in practice. The trade diversion that operates here concerns intermediate, rather than final, products. ROOs with high restrictiveness within the middle range (e.g., $60 \%$ to $80 \%$ value added) will cause a greater degree of trade diversion in intermediate productsthat is, where some form of "component cumulation" is allowed. I use the term "component cumulation" to mean that intermediate products from within the cumulation area (e.g., from FTA members) will be counted as local components

\footnotetext{
Michael Finger, “Gatt's Influence on Regional Arrangements,” in Jamie De Melo and Arwind Panagariya (eds.), New Dimensions in Regional Integration 155 (Center for Economic Policy Research, Cambridge University Press. 1993); Frieder Roessler, "The Relationship Between Regional Integration Agreements and the Multilateral Trade Order," in K. Anderson and R. Blackhurst (eds.), Regional Integration and the Global Trading System at 314 (Harvester Wheatsheaf, 1993); Jacob Viner, The Customs Union Issue 51 (Carnegie Endowment, 1950).

${ }^{27}$ See, e.g., Robert Hudec, Developing Countries in the GATT Legal System (Gower, 1987) (especially chapters 9-11).
} 
for origin purposes. In other words a producer in a beneficiary country will have an incentive to use more expensive cumulation-region components in a final product in order to qualify for duty-free access to the preferential market (for the final product). In some circumstances more expensive intermediate products from within the cumulation region will displace less expensive intermediate products from outside the region-resulting in trade diversion in intermediate products.

For a classic example of this phenomenon consider the NAFTA origin rule for ketchup. ${ }^{28}$ The rule is restrictive; it does not allow the process of converting tomato paste into ketchup (which would seem to be a substantial transformation) to confer origin. The rule thus appears aimed at ensuring that U.S. ketchup manufacturers will use Mexican tomato paste (a NAFTA origin component that counts as an originating input) in their production of ketchup instead of cheaper tomato paste from Chile (not a NAFTA member). As preferential ROOs move toward the more restrictive end of the middle range (in essence requiring higher and higher value added), more and more trade diversion in intermediate products will occur-again, as long as regional component cumulation is permitted in the ROOs regime. The discussion below argues that both regional component cumulation and restrictive ROOs should be avoided in FTA regimes, including in any harmonization effort for the applicable ROOs. Indeed, the discussion goes a step further to argue that generally both regional component cumulation and highly restrictive ROOs are inconsistent with existing WTO rules.

\footnotetext{
${ }^{28}$ The example comes from David Palmeter, The WTO as a Legal System-Essays on International Trade Law and Policy at 142-143; 149-151 (Cameron May, London, 2003); David Palmeter, "Rules of Origin in Regional Trade Agreements,” in Paul Demaret, Jean-Francois Bellis, \& Gonzalo Garcia Jimenez, Regionalism and Multilateralism aftter the Uruguay Round at 343-344 (European Interuniversity Press, Brussels, 1997).
} 


\section{Cumulation, Restrictive ROOs, and Trade Diversion in Intermediate}

Products. Component cumulation is normally a feature of all FTA agreements. ${ }^{29}$ At first blush it seems only logical that intermediate products from within the region should be counted as helping to confer origin, because such products do not pose the risk of trade deflection from outside the regionthe very trade pattern that ROOs are designed to prevent. However, it is component cumulation itself in ROOs regimes that is a major culprit in causing intermediate-product trade diversion. Once component cumulation is in place, regional intermediate good producers have every incentive to push for more restrictive ROOs in the middle range. Restrictive ROOs combined with regional component cumulation then operate in tandem to cause trade diversion in intermediate products. I will argue below that both component cumulation and excessively restrictive ROOs in FTAs should be seen as generally inconsistent with GATT Article XXIV. If regional component cumulation were eliminated from FTA agreements, the pressure for more restrictive ROOs coming from intermediate good producers--at least those not located in the final assembly country--would be significantly reduced, because such producers would no longer benefit from restrictive ROOs.

Were the component cumulation rule eliminated in FTA arrangements, intermediate good producers within the final assembly country would then have an incentive to lobby for restrictive ROOs in order to block competition from other FTA intermediate good producers. Given that components from other FTA partners would not qualify to confer origin, sufficiently restrictive ROOs could force the use of local, as opposed to other-FTA, components. In the case of third-country components, tariffs would presumably afford adequate

\footnotetext{
29 For a thorough discussion of different cumulation rules and of the cumulation provisions in a number of FTA arrangements, see Paul Brenton, Notes on Rules of Origin with Implications for Regional Integration in Southeast Asia, (paper prepared for Pacific Economic Cooperation Council, April 22-23, 2003).
} 
protection, ${ }^{30}$ but with tariffs eliminated on FTA intermediate goods, restrictive ROOs could substitute as a form of protection against the use other-FTA components as well.

Inefficient final good producers would also have similar incentives to favor restrictive ROOs, although in their case they would lobby for ROOs at the extreme end of restrictiveness so that very few final goods from FTA partners could ever qualify for tariff-free access in the first place. I will argue below that using restrictive ROOs to constrain intra-FTA trade (on intermediate goods and on final goods) should be seen as inconsistent with WTO rules, namely GATT Articles XXIV and III(4).

The upshot of this analysis and the discussion to follow is to favor a formula for harmonized PROOs that would prohibit component cumulation and hold the restrictiveness of preferential ROOs to the lower middle range. This would serve to limit some of the trade diverting effects associated with PROOs themselves, while still preventing trade deflection and ensuring that a genuine "substantial transformation" occurs in the country of origin before a local good could benefit from a regional preference.

I turn below to a fuller discussion of the ways in which existing WTO rules may apply to discipline preferential ROOs. As mentioned, I will argue that in the case of FTA agreements these rules should be seen to prohibit both component cumulation and excessively restrictive ROOs. In the case of GSP systems, I believe WTO rules have less significance for ROOs, but they still should be seen to prohibit bilateral cumulation- to be explained below.

\footnotetext{
${ }^{30}$ One might wonder how drawback rules would affect this scenario. Normally tariff drawbacks are not allowed on trade benefiting from a regional preference. Thus, if Mexico imposes a tariff on tomato paste from Chile, that tariff could not be drawn back on the export to the United States of Mexican catsup made from Chilean tomato paste. Hence a sufficiently high Mexican tariff on Chilean tomato paste would still encourage Mexican catsup makers to use Mexican tomato paste for catsup destined for the U.S. market.
} 


\section{THE POTENTIAL OF WTO RULES TO DISCIPLINE PROOS}

WTO provisions, namely in Articles XXIV and III and in the Enabling Clause, especially as interpreted in Appellate Body (AB) rulings, have important implications for the content of preferential ROOs. ${ }^{31}$ Although one can never rule out a WTO complaint attacking ROOs provisions, ${ }^{32}$ my purpose in the following discussion is primarily to urge a harmonization approach that avoids legal difficulties. I turn first to FTA agreements where WTO requirements may have greatest significance and then to GSP systems.

\section{Free Trade Area Agreements}

Discrimination Against Third Countries. As already noted, FTA preferences are approved under WTO rules if they meet the requirements of GATT Article XXIV. The key Article XXIV provisions for our purposes are XXIV(4), XXIV(5) (chapeau), XXIV(5)(b), and XXIV(8)(b). We turn first to Article XXIV(5)(b), which provides:
"with respect to a free-trade area, *** the duties and other regulations of commerce maintained in each of the constituent territories and applicable at the formation of such free-trade area $* * *$ to the trade of contracting parties not included in such area or not parties to such agreement shall not be higher or more restrictive than the corresponding duties and other

\footnotetext{
31 For a different but not inconsistent analysis of how WTO rules might apply to ROOs regimes, see generally James Mathis, Regional Trade Agreements in the GATT/WTO: Article XXIV and the Internal Trade Requirement 145-170 (The Hague, 2002) (citing GATT documents raising various legal considerations).

32 There has been one WTO complaint procedure so far, based, however, on non-preferential ROOs. See United States-Rules of Origin for Textiles and Apparel Products, WT/DS243/R (June 20, 2003) (panel's rejection of India's complaint against the U.S. ROO for textiles was not appealed to the AB).
} 
regulations of commerce existing in the same constituent territories prior to the formation of the free-trade area $* * *$ " (Emphasis added)

Thus, Article XXIV(5)(b) contemplates that members of an FTA will each retain the external tariff and other barriers (which may not be increased) that prevailed prior to forming the FTA. The need for ROOs derives from this feature of FTAs - the continued existence in each FTA member state of its own (non-harmonized) tariff and quota regime applicable to third countries. In a customs union the external tariff is harmonized. Thus, any product shipped from one member country to another can be accepted duty-free, because that product and its components would have faced the same tariff levels and other restrictions, irrespective of the port of entry. But in an FTA, only products that have undergone some level of processing in the member country from which they are shipped will be given duty-free treatment. Otherwise, third countries will simply transship through the country with the lowest external tariff, and the FTA will be converted into a de facto customs union with an applicable external tariff equal to the lowest tariff rate prevailing among the members.

In the second edition of their well-known book on the world trading system, Trebilcock and Howse proposed that Article XXIV(5) be amended to require all FTA members to apply the lowest tariff level prevailing among the members. ${ }^{33}$ Such a system would in effect do away with FTAs and convert all such agreements—or at least all such future agreements, assuming that existing agreements would be grandfathered - into customs unions. Indeed, it is hard to see why countries would ever agree to an FTA on the Trebilcock and Howse terms, instead of negotiating an overt customs union involving the harmonization of external tariff levels (with some going up and some coming down) — unless the members had almost identical tariff schedules to begin with.

\footnotetext{
${ }^{33}$ Michael Trebilcock \& Robert Howse, The Regulation of International Trade at 520 (2d ed. 1999)
} 
Converting FTAs into customs unions could be a promising way to eliminate the need for ROOs and the complexities and transactions costs that go with them. If the political will existed, WTO members might consider a variation of the Trebilcock and Howse proposal. This variation would consist of requiring a mini-customs union to operate for all goods on which existing tariff levels among the FTA members (for the stated good and most of its components) did not exceed an agreed level of variance. For such goods ROOs would not be needed. Moreover, FTA members might be required to negotiate over time the inclusion of an ever larger percentage of FTA trade within the mini-customs union regime. Of course customs unions also involve trade diversion in both final and intermediate goods, though they do away with restrictive ROOs aimed significantly (if not exclusively) at trade diversion in intermediate goods. One writer has even urged that Article XXIV be amended to prohibit FTAs and allow only customs unions. ${ }^{34}$

Another method for eliminating the need for ROOs might be called a "Value-Added FTA" scheme. ${ }^{35}$ Since the risk of trade deflection is the central (if not only) justification for PROOs, trade deflection might be avoided by an equalizing tariff imposed at all internal FTA borders. The equalizing tariff would represent the difference in external tariff rate (as between the exporting and importing FTA members) that would apply on all third-country components - as long as the importing FTA member's rate were higher. Such a scheme could be interpreted to meet the requirements of Article XXIV(8)(b) (“duties $* * *$ are eliminated on substantially all the trade between the

\footnotetext{
${ }^{34}$ F. A. Haight, "Customs Unions and Free-Trade Areas under GATT,” 6 Journal of World Trade 391, 401 (1972).

35 For a discussion of essentially the same proposal, see James Mathis, Regional Trade Agreements in the GATT/WTO: Article XXIV and the Internatl Trade Requirement at 169 (The Hague, 2002).
} 
constituent territories in products originating in such territories”) if “products originating in such territories” were interpreted to mean "products, or components (including value added) originating in such territories.” Thus, nonoriginating components could be subjected to an equalizing tariff. ${ }^{36}$

Even without such radical proposals, however, existing WTO rules, especially as interpreted by the $\mathrm{AB}$, have the potential to discipline the trade diverting capability of ROOs in FTAs. The AB's Turkish Textiles ${ }^{37}$ decision is central to this analysis.

Turkish Textiles and Article XXIV. In Turkish Textiles the AB read the chapeau of Article XXIV(5), in the light of XXIV(4), to impose constraints on the formation of a regional arrangement. The relevant provisions are as follows:

\section{Article XXIV(4)}

“[T]he purpose of a customs union or of a free trade area should be to facilitate trade between the constituent territories and not to raise barriers to the trade of other contracting parties with such territories." (Emphasis added)

\footnotetext{
${ }^{36}$ Apart from the administrative demands of such a scheme, it would also be less generous to intra-regional trade than a system based on liberal ROOs without cumulation. In the latter scheme some extra-regional components in a final product would move tariff free between FTA members, as long as the product undergoes a “substantial transformation” in the exporting FTA member.

37 Turkey - Restrictions on Imports of Textile and Clothing Products, WT/DS34/AB/R (1999).
} 
Article XXIV(5) (chapeau)

"Accordingly, the provisions of this Agreement shall not prevent, as between the territories of contracting parties, the formation of a customs union or of a free trade area $* * *$ ”

Relying on this language, the $\mathrm{AB}$ ruled that in forming a customs union with the EC, Turkey was not allowed to impose a new quota on Indian textiles to conform to the existing EC quota under the WTO Agreement on Textiles and Clothing. The AB found that such a Turkish quota would raise a new barrier against a third party (India) on textile imports into Turkey and that this new barrier was not necessary to the formation of the customs union. Hence it clashed with the paragraph 4 requirement that a customs union or FTA must be for the purpose of facilitating trade within the regime and not for the purpose of raising barriers against third countries. Acknowledging that the EC would not be willing to tolerate trade deflection of third-country textiles into the EC through Turkey, the AB concluded that Turkey could just as well employ a ROOs regime to prevent circumvention of the EC quota. In effect, the $A B$ required Turkey to use this least restrictive means to achieve the legitimate end of a customs union with the EC.

The core concept in Turkish Textiles seems directly applicable to restrictive ROOs cum component cumulation in FTAs. As discussed above, it is actually the regional-component cumulation rule in an FTA agreement that encourages trade diversion in intermediate products, thereby raising barriers against third-country intermediate good exports to the region. Restrictiveness in ROOs of course accentuates this effect. Prior to the FTA, regional producers would have imported the least cost components, after taking account of applicable tariffs. However, after the formation of the FT--given regional- 
component cumulation--they would in some cases substitute more expensive regional inputs in order to qualify for the preference. The more restrictive the ROOs the more often they would do so. Thus the component-cumulation rule applied on the formation of an FTA will operate to raise barriers (non-tariff barriers) against intermediate product imports from outside the region. ${ }^{38}$

If the purpose of an FTA agreement should be to increase trade among the FTA members, while not "raising barriers to the trade of other contracting parties,” as stated in XXIV(4), then the component-cumulation rule violates XXIV(4--at least in any case in which a third country's input is displaced because of the component-cumulation rule. An FTA can be created and can serve its intended purpose of expanding regional trade (through removing barriers on that trade) without at the same time raising barriers against third country intermediate products. What is needed is to remove the componentcumulation rule.

In the absence of component cumulation, final good producers would have no reason to substitute a more expensive partner-FTA input for a less expensive third-country input in order to satisfy a ROO requirement for "local” content. Removing component cumulation would also remove a pressure group (regional intermediate good producers who ship to a final good producer in a different FTA member) from the political coalition that would otherwise press for more restrictive ROOs—so that ROOs themselves might consequently be less restrictive.

\footnotetext{
38 A discussion paper of the Centre for Economic Policy Research reaches a similar conclusion about the effect of restrictive ROO but characterizes that effect as the equivalent of an export subsidy to intra-regional exports of intermediate products. The central point remains that more expensive intermediate products from within the region will displace cheaper extra-regional intermediate products-the essence of an increased non-tariff barrier to extra-regional intermediate products. See Olivier Cadot, Antoni Estevadeordal, \& Akiko Eisenmann, Rules of Origin as Export Subsidies (Discussion Paper No. 4999 of the Centre for Economic Policy Research, April 2005) (available online at: www.cepr.org/pubs/dps/DP4999.asp and at www.ssrn.com/abstract=772070)
} 
Article XXIV(5)(b), which we discussed above, also supports this analysis. The important language in this context is as follows:

"[W]ith respect to a free trade area $* * *$ the duties and other regulations of commerce $* * *$ shall not be higher or more restrictive than the corresponding duties and other regulations of commerce existing in the same constituent territories prior to the formation of the free trade area $* *$ *.” (Emphasis added) ${ }^{39}$

Government documents openly acknowledge that preferential ROOs are instruments of commercial policy. ${ }^{40}$ Hence it should follow that they constitute "other regulations of commerce" in the sense of Article XXIV(5)(b). If this is so, a component-cumulation rule that operates to restrict intermediate product imports from third countries into an FTA region would run afoul of XXIV(5)(b)'s prohibition on such increased restrictions--in addition to clashing with the chapeau of XXIV(5) read in the light of XXIV(4).

Discrimination Against FTA Partners. As mentioned earlier, there are two respects in which removal of component cumulation would not affect the self-interest of certain groups to press for excessively restrictive FTA ROOs, which in turn would lead to trade diversion. For these cases, however, other WTO provisions come into play.

\footnotetext{
${ }^{39}$ In the case of a customs union the equivalent provision of $\operatorname{XXIV(5)(a)~says~that~duties~and~other~regulations~}$ of commerce shall not "on the whole be higher ***." This is because for a customs union some external barriers must be raised while others must be lowered to form a common external commercial policy against third parties In the case of an FTA, however, there is no justification for any increase in an external barrier against third country trade.

${ }^{40}$ See European Commission, Green Paper: "On the Future of Rules of Origin in Preferential Trade Arrangements," at 7 (COM(2003) 787 final; December 18, 2003. ("The preferential rules of origin are an instrument of commercial policy.” (Emphasis in original). The Green Paper's approach to preferential ROOs contrasts sharply with the ROO Agreement's provisions on non-preferential ROOs. See, e.g., ROO Agreement Article 2 (b): "[N]otwithstanding the measure or instrument of commercial policy to which they are linked, ** * [Members shall ensure that non-preferential rules of origin are not used as instruments to pursue trade objectives directly or indirectly; ***”
} 
First there is the possibility that under a regime disallowing component cumulation, local intermediate good producers would have an incentive to seek restrictive ROOs for protection against more efficient intermediate goods from FTA partner countries. FTA partner inputs would enter tariff free but could not be used to satisfy a restrictive ROO. Thus a restrictive ROO (for the final product) could be used to block imports of cheaper FTA-partner intermediate goods (in favor of using more expensive local intermediate goods) so that the final product would qualify as having regional origin. Here, however, Article III(4) providing for national treatment on regulations affecting the internal sale of goods would seem to apply. The relevant Article III(4) language is as follows:

"The products of $* * *$ any contracting party imported into the territory of any other contracting party shall be accorded treatment no less favorable than that accorded to like products of national origin in respect of all laws, regulations and requirements affecting their internal sale ***” (Emphasis added)

ROOs going beyond what would be needed to prevent trade deflectionfor eample, ROOs more restrictive than needed to capture "substantial transformation" — would seem to run afoul of Article III(4) —at least if the ROOs were so restrictive that they could only be met with the use of local components (as opposed to other forms of local value added processing). ${ }^{41}$ In that situation, partner FTA components would be treated less favorably than local components. Of course allowing component cumulation would eliminate

\footnotetext{
41 The AB analyzed a closely analogous issue in Canada-Certain Measures Affecting the Automotive Industry, WT/DS 139 \& 142/AB/R (2000). There the question was whether the Canadian scheme of tariff preferences operated as a prohibited import substitution subsidy under Article 3.1(b) (prohibiting a subsidy contingent on the use of domestic over imported goods). The AB concluded that a violation could be found if the value-added requirement of the Canadian scheme were so demanding that it could only be met through the use of domestic components, as opposed to other aspects of value added, such as local labor costs in processing.
} 
this difficulty, but would at the same time open up WTO-inconsistent barriers to inputs from third countries. ${ }^{42}$ Instead the proper WTO-consistent remedy would be to remove the unnecessary restrictiveness in the FTA ROOs regime.

Second, removal of component cumulation would not deter regionally less efficient final good producers from pressing for the most restrictive ROOs possible. ${ }^{43}$ As we have seen, such ROOs would limit the number of products (in this case final goods) that could practically comply and would hence reduce the number of regional final goods entering a competitor's market at preferentially reduced duty rates. However, this protectionist effect would tend to clash with the Article $\mathrm{XXIV(8)(b)} \mathrm{requirement} \mathrm{that} \mathrm{an} \mathrm{FTA} \mathrm{should} \mathrm{eliminate}$ restrictions on substantially all trade. Highly restrictive ROOs that constrain or completely block the availability of preferential access of a final good would thus in effect reduce the amount of trade benefiting from duty-free access. The more this effect occurs under an FTA agreement the more questionable it becomes whether the given FTA agreement complies with the "substantially all trade” requirement of Article XXIV(8)(b). ${ }^{44}$

\section{Many observers may feel instinctively that some accommodation of} protectionist pressures within an FTA region will be unavoidable. Even so, a

\footnotetext{
${ }^{42}$ We can now see that Article III(4) is also applicable to challenge excessively restrictive ROOs that operate to favor local intermediate products over third country inputs where, for example, external tariffs would not block such trade. In this situation it would not be the component cumulation rule that contrained third country intermediate product imports, but rather the restrictiveness of the ROOs alone.

Moreover, Article III(4) as applicable through the MFN principle in Article I, raises a further argument against the legality of component cumulation, because component cumulation gives less favorable treatment to thirdcountry intermediate products than to partner FTA intermediate products. This is not an effect coming from free trade accorded to partner FTA intermediate products, which Article XXIV allows, but rather from the component cumulation rule in tandem with restrictive ROOs. This violation of the Article I MFN principle (incorporating Article III(4)) would not seem to be excused in the light of the Turkish Textiles interpretation of Article XXIV (4) and (5), because it would not be necessary to the formation of the FTA.

43 Intermediate good producers, on the other hand, would prefer ROOs sufficiently restrictive to eliminate competitors, but not so restrictive as to prevent the final product from gaining preferential access.

${ }^{44}$ Of course this same Article XXIV(8)(b) argument also would apply to the use of restrictive ROOs short of the prohibitive level for the purpose of protecting local intermediate good producers from more efficient intermediate good producers in other FTA countries.
} 
special safeguard regime applicable within an FTA agreement would seem preferable to restrictive ROOs. ${ }^{45}$ Temporary safeguards could be employed where the influx of regional trade causes excessive dislocation. Thus the remedy would be more suited to the real risk, and the FTA regime would be unburdened by restrictive ROOs.

Harmonized NPROOs as a Model for Harmonizing FTA ROOs. In the light of the above legal analysis, it would seem that any set of harmonized ROOs for FTAs should eliminate regional component cumulation and should favor less restrictive over more restrictive ROOs. A good model for such an approach would be the set of harmonized NPROOs currently being negotiated in Geneva under the ROOs Agreement. Those ROOs will not include cumulation and are generally acknowledged to be more "neutral" and less restrictive than the PROOs that are generally applied in preferential arrangements. Moreover harmonizing NPROOs and PROOs around a single set of ROOs would be a boon to transparency and simplification in the world trading system.

The European Commission has argued against this approach, calling it a "false good idea." ${ }^{46}$ Its reasons for that conclusion, however, seem unpersuasive. They fall into three categories. First the Commission prefers an across-the-board value-added approach to PROOs as compared to the harmonized rules' change-of-tariff-heading (CTH) approach. This is not a principled objection to having one uniform set of ROOs. Whichever approach is preferred, CTH or value-added, it could be preferred for both preferential and non-preferential ROOs.

\footnotetext{
45 For an analysis concluding that regional safeguards are consistent with WTO rules, see Joost Pauwelyn, “The Puzzle of WTO Safeguards and Regional Trade Agreements,” 7 Journal of International Economic Law 109 (2004). For further discussion of this issue see James Mathis, Regional Trade Agreements in the GATT/WTO: Article XXIV and the Internal Trade Requirement (The Hague, 2002) (Chapter 9 at 171-190 addresses "Regional Safeguards and Restrictive Measures).

46 European Commission, Working Paper: "Justification of the Choice of a Value Added Method for the Dertermination of the Origin of Processed Products,” at 6 (TAXUD/1121/05 Rev. 1; April 20, 2005).
} 
Second, The Commission notes that NPROOs support measures such as quotas and trade-remedy barriers that restrict market access, whereas PROOs support improved access to markets. But why should this distinction matter? For ROOs of both types the central issue is (or should be) to identify when a good can "legitimately" be said to originate in a particular country-which generally means that enough processing has occurred there to cause significant transformation. If more than that is required for PROOs-as compared to NPROOs—one may legitimately ask "why". The main reason would seem to be to encourage trade diversion for intermediate products - which, as we have seen, clashes with WTO rules.

Third, and most important, the Commission openly acknowledges that a goal of PROOs is to encourage sourcing (even of a more expensive intermediate good) within the relevant "cumulation zone."47 It admits that PROOs are more restrictive and not as "neutral" as the harmonized NPROOs. It claims that PROOs cannot be so "neutral” because they form a part of the EU's "external policies and negotiations." ${ }^{48}$ These published views of the Commission have a "smoking gun" quality about them. They claim as a goal the very trade diversionary policies that seem to violate WTO rules.

The Commission should be commended for its openness in discussing these issues. It seems almost certain that the same perspectives and considerations come into play in other countries that adopt restrictive PROOs,

\footnotetext{
47 See European Commission, Working Paper: "Justification of the Choice of a Value Added Method for the Dertermination of the Origin of Processed Products,” (TAXUD/1121/05 Rev. 1; April 20, 2005). In arguing for a value-added approach to PRO the Commission asserts: "Value-added method would be an incentive to source originating materials (even if more expensive than the non originating ones) from the exporting country or from a country belonging to the same cumulation zone ***.” Id. at 7.

48 Id. at 6 ("PRO [preferential rules of origin] are clearly not as 'neutral' as the NPRO [non-preferential rules of origin] but an integral part of external policies and negotiations ***.”)
} 
even though they are not as forthright as the Commission in revealing their motives.

In sum, the harmonized system being developed for NPROOs would seem a good model for PROOs applicable to FTAs. NPROOs have no cumulation provisions, and they are generally less restrictive. Hence they will minimize trade diversion in intermediate products and they will not undermine the “substantially all trade” requirement of Article XXIV(8)(b).

It should be noted that the analysis just presented would not technically apply to an FTA arrangement limited exclusively to developing countries. Such an arrangement would be authorized by the Enabling Clause and would not need to comply with Article XXIV for legitimacy. The Enabling Clause authorizes an exception to the core MFN requirement for: "Regional or global arrangements entered into amongst less-developed contracting parties for the mutual reduction or elimination of tariffs and $* * *$ non-tariff measures, on products imported from one another."49 As a practical matter, however, if industrial countries were willing to agree to harmonize PROOs for FTAs along the lines just proposed, it would seem unfortunate to sacrifice simplicity, transparency and coherence by excluding developing country FTAs from that regime. On the other hand, proponents of special and differential treatment for developing countries might consider the S\&D goal important enough to justify more restrictive ROOs for developing country FTAs.

\footnotetext{
49 Decision on Differential and More Favorable Treatment Reciprocity and Fuller Participation of Developing Countries, GATT Document L/4903, 28 November 1979, BISD 26S/203, para. 2(c). One might note that the term here is "less-developed" and not "developing”. The Enabling Clause distinguishes between developing and least-developed countries, but it appears to use the term "less-developed” as interchangeable with "developing”.
} 


\section{GSP Systems}

In the case of GSP systems it is again the Enabling Clause, and not Article XXIV, that has implications for the content of PROOs. In this context, trade diversion in intermediate products does not pose a legal problem—at least not as long as the favored producers are in other developing countries. The Enabling Clause authorizes preferences that benefit developing country producers. It should not matter whether those producers make intermediate or final products, or whether trade creation or trade diversion is involved.

However, some GSP systems, including those applied by the United States and the EU, incorporate bilateral cumulation. ${ }^{50}$ Cumulation is bilateral when intermediate products imported from the preference-granting country count as local value added in the beneficiary developing country. It is hard to square this with the Enabling Clause, especially as interpreted by the AB's EC-Tariff Preferences decision. ${ }^{51}$ That decision found that footnote 3 to the Enabling Clause had binding force in limiting GSP systems. The important language in the footnote incorporates into the Enabling Clause the conditions imposed in the 1971 GATT decision authorizing GSP systems for the first time:

\footnotetext{
"As described in the Decision of the CONTRACTING PARTIES of 25 June 1971, relating to the establishment of "generalized, non-reciprocal
}

\footnotetext{
50 For a description of some of the bilateral cumulation elements of the ROO regime applicable in the United States under the African Growth and Opportunity Act (AGOA), see Raj Bhala, "The Limits of American Generosity,” 29 Fordham International Law Journal 299, 356-376 (Issue \#2, 2006). For a description of bilateral cumulation in the GSP regime applicable in the EU, see Paulette Vander Schueren \& Michal Cieplinski, "EC Generalized System of Tariff Preferences in the Making: Improved Market Access for Developing Countries,” 11 International Trade Law \& Regulation 118,122-123 (Issue \#4, 2005).

${ }^{51}$ EC-Tariff Preferences, WT/DS246/AB/R (2004).
} 
and non-discriminatory preferences beneficial to the developing countries. 52

Bilateral cumulation would seem to violate this provision in two ways. First, it is inconsistent with a "non-reciprocal" regime. Bilateral cumulation favors the use of intermediate products from the preference-granting country and in that sense is reciprocal. Second, trade diversion in favor of intermediate products sourced in the preference granting country assists producers in that country, instead of developing country producers.

It might be argued that bilateral cumulation also assists developing countries, because it allows them more flexibility in satisfying the origin rule, which, if it is not satisfied, would deny the preference. However, an alternative that does not clash with the Enabling Clause exits. A preference granting country could drop bilateral cumulation and at the same time relax the restrictiveness of the applicable ROOs so that an equivalent amount of trade from developing countries would qualify for preferential treatment. One way to do so would be to liberalize the ROOs in a general way (e.g., reduce the required local value added percentage). Another would be to adopt or expand "tolerance rules” under which a certain amount of non-originating materials would be treated as local, no matter where they actually originated. This would increase the flow of goods able to take advantage of the preference, without privileging grantor-country intermediate products.

\footnotetext{
52 Decision on Differential and More Favorable Treatment Reciprocity and Fuller Participation of Developing Countries, GATT Document L/4903, 28 November 1979, BISD 26S/203, para. 2(a) fn 3.
} 
CURRENT EFFORTS AT HARMONIZING PROOS (THE INITIATIVE WITHIN THE EU)

As noted earlier, efforts to launch a harmonization initiative for PROOs at the WTO level have so far failed. Within the EU, however, considerable attention is being devoted to the benefits of harmonizing the EU's own PROOs. ${ }^{53}$

The EU's current approach to preferential ROOs is dramatically nonuniform. The EU has about 40 different preferential arrangements in place (GSP and FTA systems) ${ }^{54}$ and almost as many different sets of ROOs, generally called the "list rules". The list rules apply product by product or by category of product. Currently there are 545 different list rules, corresponding to 509 different categories of product, and an additional 107 alternative rules. ${ }^{55}$ Although the current list rules vary with each particular preferential regime, their general "architectural" structure follows fairly closely that of the harmonized NPROOs currently under negotiation in Geneva. That is to say, the rules use a combination of CTH, Value Added (VA), and Specific Processing (SP) requirements. ${ }^{56}$

\footnotetext{
53 For a summary of the existing EU GSP regime and the proposed new regime, see Paulette vander Schueren and Michal Cieplinski, "EC Generalized System of Tariff Preferences in the Making: Improved Market Access for Developing Countries,” 11 International Trade Law \& Regulation 118 (Sweet \& Maxwell, 2005).

There seems to be nothing comparable to the EU harmonization effort in the United States or other countries. In the United States, in particular, the GSP ROOs are reasonably uniform already. They rely essentially on the substantial transformation test plus generally a 35\% value-added requirement. See generally, David Palmeter, "Rules of Origin in the United States" in Ewin Vermulst, Paul Waer, \& Jacques Bourgeois, Rules of Origin in International Trade - A Comparative Study at 58-84 (University of Michigan, Ann Arbor, 1994). The ROOs for NAFTA, however, are dramatically different, involving a basic CTH approach supplemented by VA and SP requirements. Id. (describing the ROOs for the Canada-U.S. Free Trade Area, which are broadly similar, though not identical, to those applied in NAFTA.)

54 European Commission, “Customs: Strategy for Simplified Rules of Origin - Frequently Asked Questions (MEMO/05/95; 17 March, 2005) at p. 1.

${ }^{55}$ European Commission, Working Paper: "Justification of the Choice of a Value Added Method for the Dertermination of the Origin of Processed Products," (TAXUD/1121/05 Rev. 1; April 20, 2005) p. 3.

${ }^{56}$ Id. at p. 3.
} 
The European Commission is urging the EU to adopt a single harmonized set of ROOs for all its preferential arrangements, GSP systems and FTAs alike. ${ }^{57}$ This effort has focused mainly on the development schemes--seeking simplification and liberalization--because the EU is preparing a new GSP regime for the period 2006-2015 and is opening negotiations on new regional Economic Partnership Agreements (EPAs) with the African-Caribbean-Pacific (ACP) countries. ${ }^{58}$ The harmonized ROOs are also intended for FTA agreements, ${ }^{59}$ presumably for future such agreements or where existing agreements can be renegotiated.

The Commission favors an across the board value added system. Origin would be conferred if local (or cumulated regional) value added exceeds a certain stated percentage of net production cost (NPC). NPC would include the cost of components and production costs directly attributable to output (such as labor, energy, plant and equipment) but would exclude overhead and related costs not directly attributable to production (such as marketing, administrative costs, and profit mark-up). ${ }^{60}$ The Commission claims that the instability introduced by exchange rate and price changes can be dealt with through an averaging system and that administrative costs should not be excessive because producers regularly keep track of production costs for many purposes, including

\footnotetext{
57 See European Commission, Green Paper: "On the Future of Rules of Origin in Preferential Trade Arrangements,” (COM(2003) 787 final; December 18, 2003; European Commission, "The Rules of Origin in Preferential Trade Arrangements - Orientations for the Future,” (COM(2005) 100 final; March 16, 2005); European Commission, Working Paper: "Justification of the Choice of a Value Added Method for the Dertermination of the Origin of Processed Products,” (TAXUD/1121/05 Rev. 1; April 20, 2005).

58 European Commission, "The Rules of Origin in Preferential Trade Arrangements - Orientations for the Future,” (COM(2005) 100 final; March 16, 2005) at p. 6.

59 European Commission, Working Paper: "Justification of the Choice of a Value Added Method for the Dertermination of the Origin of Processed Products,” (TAXUD/1121/05 Rev. 1; April 20, 2005) p. 4.

60 See Eckart Naumann, Rules of Origin under EPAs: Key Issues and New Directions (paper for Tralac Conference, October 2005) p. 18 (available at http://www.tralac.org/pdf/20051018_ROO_paper.pdf).
} 
pricing. ${ }^{61}$ There are of course other disadvantages to a VA system, such as the lack of an incentive to keep local production costs down and the bias against countries with low labor costs. However, other systems also have their drawbacks.

A major disadvantage of this initiative, however, is that it clashes with the multilateral NPROOs system being negotiated in Geneva under the ROOs Agreement. As discussed in the opening section of this essay, the multilateral NPROOs system under negotiation will rely primarily on a CTH approach, supplemented on certain tariff lines by value-added and special-processing rules. If PROOs and NPROOs go their separate ways, overall harmonization in the future will be made more difficult. Although the Commission considers joining the two major types of ROOs to be a "false good idea," ${ }^{62}$ the analysis presented above disagrees with that conclusion.

\section{CONCLUSION}

This essay has argued for the importance of launching an effort at the WTO level to harmonize PROOs. Such an undertaking is not likely to be taken seriously, however, until after the WTO members successfully negotiate a harmonized set of NPROOs, which at this writing is long overdue. I have argued further that harmonized NPROOs-which are expected to be relatively non-restrictive and neutral, based on the concept of "last substantial transformation”-would provide a good model for a harmonized set of PROOs. In particular I have claimed that existing WTO rules, namely Article XXIV (4) (5) and (8)(b) and Article III(4), are most consistent with a set of PROOs that

\footnotetext{
61 European Commission, Working Paper: "Justification of the Choice of a Value Added Method for the Dertermination of the Origin of Processed Products,” (TAXUD/1121/05 Rev. 1; April 20, 2005) p. 8.

62 European Commission, Working Paper: "Justification of the Choice of a Value Added Method for the Dertermination of the Origin of Processed Products,” (TAXUD/1121/05 Rev. 1; April 20, 2005) p. 6.
} 
are non-restrictive and that do not allow component cumulation (or in the case of GSP systems, bilateral cumulation). A major aim of such an approach to PROOs is to constrain the tendency of ROOs in FTA agreements to further trade diversion in intermediate products.

Even if the most ambitious harmonization project were completely successful, however, distortive trade diversion in final and intermediate products would still inhere in preferential trading arrangements. Thus, it bears repeating-along with the Future of the WTO report and other commentators--that the most effective means of dealing with the complexities and distortions introduced into the global trade order by the burgeoning number of preferential arrangements and their accompanying ROOs is to move as aggressively as possible to lower MFN tariffs worldwide. As these come down, so will the distortions associated with preferences. On the pragmatic assumption, however, that such a first-best world will be long in coming, it still seems important to pursue harmonization of PROOs. 


\section{Bibliography}

K. Adamantopoulos \& D. de Notaris, "The Future of the WTO and the Reform of the AntiDumping Agreement: A Legal Perspective,” 24 Fordham Int'l L.J. 30 (2000) [AD anticircumvention]

Asian Development Bank, Asian Development Outlook 2006 at 276 (on line at http://www.adb.org/Documents/books/ado/2006/documents/ado2006-part3.pdf.)

Raj Bhala, “The Limits of American Generosity,” 29 Fordham International Law Journal 299, 356-376 (2006).

Robert Baldwin, The Inefficacy of Trade Policy 20 (Princeton Essays in Int'l Finance, 1982

Paul Brenton, Notes on Rules of Origin with Implications for Regional Integration in Southeast Asia, (paper prepared for Pacific Economic Cooperation Council, April 22-23, 2003).

Paul Brenton \& Hiroshi Imagawa, "Rules of Origin, Trade, and Customs” in Customs Modernization Handbook ( ).

Olivier Cadot, Antoni Estevadeordal, \& Akiko Eisenmann, Rules of Origin as Export Subsidies (Discussion Paper No. 4999 orf the Centre for Economic Policy Research, April 2005) (available online at: www.cepr.org/pubs/dps/DP4999.asp and at www.ssrn.com/abstract $=772070$ )

Frederic Cantin \& Andreas Lowenfeld, "Rules of Origin, The Canada-U.S. FTA, and the Honda Case,” 87 Amer. J. Int’l L. 375 (1993)

F. Dehousse, K.Ghemar \& P. Vicent, “The EU-US Dispute Concerning the New American Rules of Origin for Textile Products,” 36 J. World Trade 67 (2002)

European Commission, Green Paper: "On the Future of Rules of Origin in Preferential Trade Arrangements,” (COM(2003) 787 final; December 18, 2003

European Commission, "The Rules of Origin in Preferential Trade Arrangements Orientations for the Future,” (COM(2005) 100 final; March 16, 2005)

European Commission, Working Paper: "Justification of the Choice of a Value Added Method for the Dertermination of the Origin of Processed Products," (TAXUD/1121/05 Rev. 1; April 20, 2005)

Ian Forrester, “The End of Innocence” in Vermulst et al eds. at 395. 
F. A. Haight, "Customs Unions and Free-Trade Areas under GATT," 6 Journal of World Trade 391 (1972).

Bernard Hoekman, "Rules of Origin for Goods and Services” 27 Journal World Trade Law Issue 4 p 81 (1993).

Gary Horlick \& Patrick Messerlin, “Need for Coherence Among the WTO’s Escape Clauses”in J. Barceló \& H. Corbet, Rethinking the World Trading System __ (Lexington Books 2007) (forthcoming).

Robert Hudec, Developing Countries in the GATT Legal System (Gower, 1987)

Robert Hudec, Comment on Michael Finger, “Gatt’s Influence on Regional Arrangements," in Jamie De Melo and Arwind Panagariya (eds.), New Dimensions in Regional Integration 155 (Center for Economic Policy Research, Cambridge University Press. 1993).

David Leebron, “An Overview of the Uruguay Round Results,” 34 Colum. J. Transnat'l L. 11 (1995) [anti-circumvention not agreed in UR; he says this at p. 20]

James Mathis, Regional Trade Agreements in the GATT/WTO: Article XXIV and the Internal Trade Requirement (The Hague, 2002)

G. Horlick \& M. Meyer, "Rules of Origin from a Policy Perspective” in Vermulst et al eds. at 403.

Eckart Naumann, Rules of Origin under EPAs: Key Issues and New Directions (paper for Tralac Conference, October 2005) (available at http://www.tralac.org/pdf/20051018_ROO_paper.pdf).

Lucia Ostoni, “Anti-Dumping Circumvention in the EU and the US: Is There a Future for Multilateral Provisions under the WTO?” 10 Fordham J. Corp. \& Fin. L. 407 (2005).

David Palmeter, The WTO as a Legal System-Essays on International Trade Law and Policy (Cameron May, London, 2003)

David Palmeter, "Rules of Origin in Regional Trade Agreements," in Paul Demaret, JeanFrancois Bellis, \& Gonzalo Garcia Jimenez, Regionalism and Multilateralism aftter the Uruguay Round at 343-344 (European Interuniversity Press, Brussels, 1997).

David Palmeter, "Rules of Origin in the United States" in Ewin Vermulst, Paul Waer, \& Jacques Bourgeois, Rules of Origin in International Trade-A Comparative Study

(University of Michigan, Ann Arbor,1994).

David Palmeter, “Country of Origin Rules,” 128 F.R.D. 492 (1990).

Joost Pauwelyn, “The Puzzle of WTO Safeguards and Regional Trade Agreements” 7 J. Int'l Econ. L. 109 (2004).

Frieder Roessler, “The Relationship Between Regional Integration Agreements and the Multilateral Trade Order,” in K. Anderson and R. Blackhurst (eds.), Regional Integration and the Global Trading System at 314 (Harvester Wheatsheaf, 1993). 
Paulette Vander Schueren \& Michal Cieplinski, "EC Generalized System of Tariff Preferences in the Making: Improved Market Access for Developing Countries,” 11 International Trade Law \& Regulation 118,122-123 (Issue \#4, 2005).

Peter Sutherland, Jagdish Bhagwati, Kwesi Botchwey, Niall Fitzgerald, Koichi Hamada, John H. Jackson, Celso Lafer, \& Thierry de Montbrial, The Future of the WTO (WTO, Switzerland, 2004).

Michael Trebilcock \& Robert Howse, The Regulation of International Trade (2d ed. 1999)

Michael Trebilcock \& Robert Howse, The Regulation of International Trade (3d ed. 2005)

Edwin Vermulst, "Rules of Origin As Commercial Policy Instruments?_Revisited” in Edwin Vermulst, Paul Waer, \& Jacques Bourgeois, eds., Rules of Origin in International Trade - A Comparative Study 433 (1994).

E. Vermulst, P. Waer, \& J. Bourgeois, eds,, Rules of Origin in International Trade - A Comparative Study (1994). 